\title{
INTERNATIONALIZATION OF HIGH-TECHNOLOGY SECTOR IN KAZAKHSTAN: MAIN BARRIERS AND FACTORS
}

\author{
Eigirdas ŽEMAITIS, Temirlan AMAN* \\ Department of Business Technologies and Entrepreneurship, Faculty of Business and Management, \\ Vilnius Gediminas Technical University, Sauletekio av. 11, Vilnius, Lithuania \\ *E-mail: temirlan.aman@stud.vgtu.lt
}

\begin{abstract}
It was a crucial decision of the Government of Kazakhstan to change the way of the development from the raw materials sector to the innovation path. This study deals with the internationalization process of the hightechnology sector. The main views of the scholars regarding the barriers that arise in the high-tech sector in the context of internationalization are presented. The types of barriers were studied and additional ones were supplemented by the views of authors in this article. The article demonstrates the important factors that affect the high-tech sector in Kazakhstan. Data was collected from the period 2009-2017 using elements such as (Government spending on R\&D, The inflow of FDI for the high Technology Sector, Government Investment, Private Enterprise Costs, High-tech Export). Using regression, correlation analysis the supported relationship between these variables was found and interpretation of this relationship is presented. The purpose of this article was to identify factors determining a significant impact on the development of the high-tech sector in Kazakhstan. In future studies, we plan to consider more data and additional factors like the import of high-tech products to get the in-depth result. Additionally, considering the possibility to create a business model that can help to improve the current position of the high-technology sector in Kazakhstan.
\end{abstract}

Keywords: high-technology sector, internationalization, barriers, factors, correlation, regression.

\section{Introduction}

Traditional internationalization theories emphasize internationalization as the gradual process, taking many years of the adaptation to the context changes (Krikštulytė \& Korsakienè, 2016). It has been also observed that high-tech firms, more often than traditional (low-tech) ones, begin the internationalization process at inception or soon after it and, what is more, it runs faster (Daszkiewicz, 2019). The necessity for the high technologies sector's development and its modernization is determined by several problems in various scientific publications (Melnikas, 2014).

Unfortunately, a lot of researches indicate that there are not enough competitive entrepreneurs in the high-tech sector of Kazakhstan. In the period of globalization, Kazakhstan high tech sector remains in a poor position due to the several reasons: there are a smaller number of appropriate scientific studies of high technology sectors; the government did not consider the development of the high-tech sector, therefore, it stayed in a bad situation. Another study showed the most investments transferred to the developed sectors such as manufacturing industry, metallurgical, oil sectors; nevertheless, the current application of integrated innovation policy did not lead to achievement of the desired result (Dukenbayev, n.d.). It required to modify the innovative policy in a more detailed and effective way.

The main reasons are the dependence on the export of crude oil products, the less amount of highly specialized personnel. Noticeable that the government conducts changes in the business area to provide sustainable growth of the economy. According to the state strategy, the basis of the competitiveness of the economy should be the high-tech industry. In Kazakhstan, it is practically absent: in recent years (since 2003), the total production of high-tech products amounted to about $1 \%$ in the structure of GDP (Khachaturov \& Belkovskiy, 2007). Technological innovation is a key to building such an infrastructure.

The current article deals with the types of barriers that arise in the process of internationalization; factors which affect the development of the high-tech sector in Kazakhstan. The main tasks of this article are:

To identify theoretical literature related to issues of the internationalisation of the high-tech sector; to create a methodology for assessing the statement of the high-technology sector; to evaluate the components which impact to the high-technology sector in Kazakhstan. 
The essence of the practical part is to determine the influence of factors such as the inflow of FDI, Government spendings, Private Sector Expenditures for the development of high-technology sector using correlation and regression. The purpose of this article was to identify factors determining a significant impact on the development of the high-tech sector in Kazakhstan.

The internationalization process become complicated for high-tech companies.

\section{Problems related to the development of internationalization in the high-tech sector}

Along with the positive factors that appear in the process of internationalization, there are barriers that companies, small medium-sized states and enterprises faced in the sector of the high technology. The process of internationalization profitably affects to the growth of the high-tech sector, as this is facilitated by the approval of (Žemaitis et al., 2016) who state that high technology sector is strongly interconnected with internationalization and innovation activities. Majority of authors divide barriers into internal and external factors. As described by (Krikštulyte \& Korsakiené, 2016), external environmental factors are unstable economic environment and legal bases while internal environmental factors are business strategy, available resources and capabilities. The most common and additional types of barriers are highlighted in Table 1.

Table 1. The barriers of the internationalization process in the high technology sector (source: Kos-Łabędowicz, 2013; Sekliuckiene \& Maciulskaite, 2013; Singh et al., 2010)

\begin{tabular}{|c|c|c|}
\hline \multicolumn{2}{|c|}{ Typical types } & Additional types \\
\hline $\begin{array}{l}\text { Internal barriers } \\
\text { Organisational and } \\
\text { management barriers: } \\
\text { the lack of knowledge } \\
\text { (logistics, marketing and } \\
\text { management); } \\
\text { a position in the markets; } \\
\text { inappropriate control of the } \\
\text { business operations; the size } \\
\text { of the firm. } \\
\text { - Financial sources: a lack of } \\
\text { financial sources. } \\
\text { - Non-financial sources: a lack } \\
\text { of information; a lack of new } \\
\text { services; a lack of human } \\
\text { resources. }\end{array}$ & $\begin{array}{l}\text { External barriers } \\
\text { - Legal: the governmental control and } \\
\text { the restrictions; the long and difficult } \\
\text { licencing process. } \\
\text { - Political: political instability. } \\
\text { - Economic: unstable economic } \\
\text { position; the control of foreign } \\
\text { currency. } \\
\text { - Market conditions: the capacity of } \\
\text { the market; different needs of the } \\
\text { customers; intense competition. } \\
\text { - Geographical: geographical } \\
\text { differences. } \\
\text { - Cultural: intercultural differences; } \\
\text { the different assessment of the } \\
\text { products / services; the barriers of } \\
\text { language. } \\
\text { - Specific: the requirements of a } \\
\text { foreign country. }\end{array}$ & $\begin{array}{l}\text { - High cost of internationalization, } \\
\text { including analysis of new markets, } \\
\text { legal consultation cost, cost of } \\
\text { translating documentation, } \\
\text { adaptation of the products to market } \\
\text { requirements, travel costs. } \\
\text { - Existing regulations and legal } \\
\text { limitations, bureaucracy. } \\
\text { - Difficulties in capital acquisition, } \\
\text { payment delays. } \\
\text { - Difficulties in accessing necessary } \\
\text { information and knowledge. } \\
\text { - Difficulties in finding partners and } \\
\text { representatives on the new markets. } \\
\text { - Corruption; and rule of law issues. } \\
\text { - Research and education policy. } \\
\text { - Intellectual property rights. }\end{array}$ \\
\hline
\end{tabular}

In Table 1 were selected the barriers which are frequently encountered in the scientific studies. Besides, we analyzed other materials and displayed other additional types. According to the studies it was noticeable that in the most cases problems related to the internationalization were similar and divided into two groups as did it (Sekliuckiene \& Maciulskaite, 2013). It was divided into internal and external groups. By the way, it was indicated in the studies that the lack of required knowledge, management and marketing skills are the most common barriers in the high technology sector.

Basically, in most cases, the sources indicated general problems, but if analyze other studies, we can understand that the number of difficulties will increase, depending on the development of the country or company. This idea can be proved, using the method of data analysis to study materials that are related to the modernization of the high-tech sector for their future sustainable economic growth. As stated (Žemaitis et al., 2016) High technology sector plays an important role in the contemporary global economy. Global economic crisis demonstrated that high technology sector is the most immune element in the economic system. It is indicated in Table 2.

Table 2 indicates that barriers can classify due to the development of the countries in the high-technology sector. It is compared to the issues of Kazakhstan and the EU countries. Noticeably, Kazakhstan experienced the lack of promotion in international markets, absence of information about new technologies, poor experience in the area of transferring technology and others. The EU suffered weakness in networking and cooperation with partners, lack of specific categories of specialists and others. In most cases, there are many types of barriers, however, it was taken the most common of them in the high-technology sector. In Kazakhstan, there is also a weak activity of commercialization of innovative developments, as this activity remained with the state. Therefore, scholars of the old school simply do not have experience in commercializing ideas, and accordingly, they cannot pass it on to their 
students (Aslanbek, 2014). One of the conditions for the emergence of a modern high-tech market is the presence of a venture capital fund. High-risk projects are financed through venture capital. The imperfection of state legislation makes the functioning of existing funds ineffective. Therefore, it is difficult for new startup companies (Aslanbek, 2014).

Table 2. The barriers related to the development of countries in the high-technology sector (source: Melnikas, 2014; Brezink, 2014; Dukenbayev, n.d.; Chelm et al., 2017; Aslanbek, 2014)

\begin{tabular}{|l|l|}
\hline \multicolumn{1}{|c|}{ Developed countries: EU } & \multicolumn{1}{c|}{ Developing country: Kazakhstan } \\
\hline - very limited sources of energy and raw materials; & - absence of informational basis on new technologies; \\
- lack of certain types of specialists; & - bribery; \\
- a shortage of financial resources, innovation & - poor experience in the sphere of technology transfer; \\
managers; & - unready financial schemes in purchasing equipment and \\
- insufficient marketing of innovation and & technology; \\
innovative products and services, lack of research & - poor experience of commodity promotion to international \\
capabilities (especially for SMEs); & market; \\
- weakness in networking and cooperation with & - The lack of venture capital fund; \\
external partners. & - Lack of commercialization of ideas. \\
&
\end{tabular}

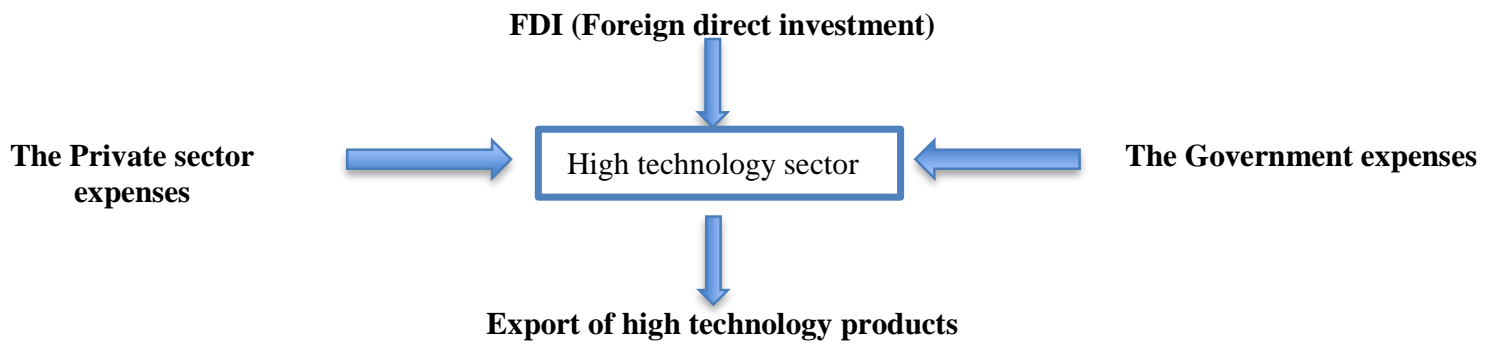

Figure 1. The factors affected the development of high-technology sector in Kazakhstan (source: Vasilyev, 2012; Dnishev et al., 2016)

Figure 1 shows factors which can affect the development of the high technology sector. The data of elements were taken to calculate using the method of empirical research. As you can see, there are three factors aimed at developing the high-tech sector, and the export of high-tech products is an effective factor. The government sector represented the data of the expenses for $\mathrm{R} \& \mathrm{D}$ and additional investments. The Private sector indicated several companies and enterprises. The high-tech industry in Kazakhstan has just begun to develop due to the active demand for innovative products. Based on this, the existing factors were selected. Today, these factors such as FDI,Private and Governtment sectors have a great influence.

\section{Research methodology for the high-technology sector in Kazakhstan}

Due to the development of the high-tech sector in Kazakhstan, the amount of research is developing in the same way. Most research uses various types and methods of research, hypotheses. In this study, scientific data allows us to use correlation and regression analysis. Figure 2 shows a process consisting of the selection of certain factors, the analysis of the correlation coefficient (Pearson correlation) and the application of regression analysis (Linear regression) to get the result.

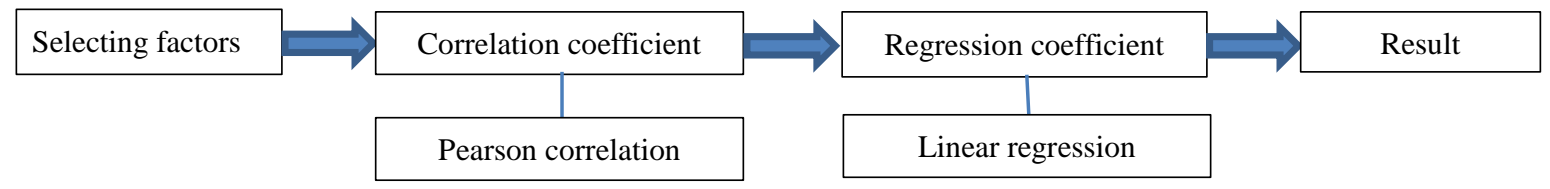

Figure 2. The process of methodological part

There are a prevailing number of factors that have a positive effect on the high-tech sector. However, there are certain elements were limited in the high-tech industry such as Government spendings, FDI, Private Enterprise Costs 
in Kazakhstan. Likewise, it is confirmed by the availability of data in the Statistics Agency of the Republic of Kazakhstan.

In this part of the methodology, were used quantitative research methods such as correlation and regression.

There are many scientific methods applied in the researches related to the high-technology sector. In most cases, there are a wide variety of methods and procedures that are preferable to use and explore an academic article such as synthesis, deduction, induction, empirical research using regression and correlation. Using the analysis method it helps to examine the main barriers and to create an appropriate model for the next investigation.

As noted earlier, the correlation coefficient method was used to study the relation of factor that affects the development level of the high technology sector and the internationalization process in the future.

The correlation method supposes to find this connection between the variables when regression analysis helps to give an explanation of the connection with using a mathematical function.

In this case, were used the scientific articles related to the literature of the high-technology sector in the context of internationalization.

The method of correlation or correlation dependence in scientific research is used as a measure of the relationship between two or more random variables. Correlation also called as correlation analysis, is a term used to denote the association or relationship between two (or more) quantitative variables (Iljin, 2013). In calculations, a change in one or more values leads to changes in other quantities. In most cases, correlation analysis is one of the most used statistical methods in scientific materials.

The correlation coefficient shows the level of dependence between two numerical variables and is calculated by the following Pearson formula:

$$
r=\frac{\sum_{i=1}^{n}\left(x_{n}-\bar{x}\right)\left(y_{n}-\bar{y}\right)}{\sqrt{\sum\left(x_{i}-\bar{x}\right)^{2} \sum\left(y_{i}-\bar{y}\right)^{2}}},
$$

where: $r$ - Pearsons correlation coefficient, $n$ - number of observations, $x$ - input variable, $y$ - output variable, $\bar{x}-$ the mean of the values of the $x$ - variable, $\bar{y}$ - the mean of the values of the $y$-variable.

(Gingrich, 2004) claimed that Values of $r$ for pairs of variables are commonly reported in research reports and journals as a means of summarizing the extent of the relationship between two variables. Pearson's $r$ summarizes the relationship between two variables that have a straight line or linear relationship with each other

The next step in the calculation is the use of regression analysis to identify a significant factor and determine how significant they are. (Aldrich, 2005) claimed The idea of regression is usually introduced in connection with the theory of correlation, but it is, in reality, a more general, and, in some respects a simpler idea and the regression coefficients are of interest and scientific importance in many classes of data where the correlation coefficient, if used at all, is an artificial concept of no real utility.

Another statement suggested by (Ramcharan, 2006) Regressions are used to quantify the relationship between one variable and the other variables that are thought to explain it; regressions can also identify how close and well determined the relationship is.

The formula is related to the simple linear regression. The linear regression is a model

$$
Y=a+b X+\epsilon,
$$

where: $Y$-dependent variable, $X$ - independent (explanatory) variable, $a$-intercept, $b$ - slope, $\epsilon$ - residual (error). The parameters $a$ and $b$ usually called regression coefficients. The unobservable error component $\epsilon$ accounts for the failure of data to lie on the straight line and represents the difference between the true and observed realization of $y$ (Shalabh, n.d.).

\section{Research results}

At this stage, the correlation coefficient was used to calculate data such as government spending on research and development, FDI, public investment, private sector spending and high-tech exports in Table 3.

The indicators from Table 3 were taken from the period of 2009 to 2017 to identify the relationship of their interdependence and based on the result, decide for the development of a particular direction.

It was presented in Figure 3 that the value of the correlation coefficient was close to 1 , then a positive relationship became between the values. In other words, a high degree of relationship between the $\mathrm{x}$ and $\mathrm{y}$ values is determined. In this case, if the $x$ values increase, then the value $y$ data will also increase (Taylor, 1990). If the correlation value was close to -1 , then a negative correlation was displayed between the variables. That is, the ratio of the variable $\mathrm{y}$ will be opposite to the variable $\mathrm{x}$. If the behaviour of the variable $\mathrm{x}$ increases, the value of $\mathrm{y}$ will decrease and vice versa. 
Table 3. The data of factors of the High-technology sector from 2009-2017 years in Kazakhstan (source: Committee of Statistics of the Ministry of National Economy of the Republic of Kazakhstan, Knoema Enterprise Data Solutions, The World Bank. Calculated by the author)

\begin{tabular}{|c|c|c|c|c|c|}
\hline Year & $\begin{array}{c}\text { Government } \\
\text { spending on R\&D } \\
\text { (billions dollar) }\end{array}$ & $\begin{array}{c}\text { The inflow of FDI for high } \\
\text { technology sector } \\
\text { (billions dollar) }\end{array}$ & $\begin{array}{c}\text { Government } \\
\text { investment } \\
\text { (additional financing) }\end{array}$ & $\begin{array}{c}\text { Private } \\
\text { Enterprise } \\
\text { Costs }\end{array}$ & $\begin{array}{c}\text { High-tech export } \\
\text { billions dollar }\end{array}$ \\
\hline 2009 & 265190000 & 1919959640 & 46373 & 400444 & 1812739413 \\
\hline 2010 & 222007500 & 2493812850 & 63097 & 1492802 & 2364844859 \\
\hline 2011 & 288900000 & 5815289650 & 216934 & 774093 & 2599205989 \\
\hline 2012 & 353600000 & 5213715044 & 303511 & 102283 & 3571435540 \\
\hline 2013 & 402220000 & 15698512680 & 15604 & 1850938 & 3112444089 \\
\hline 2014 & 376380000 & 16177137640 & 243432 & 1427540 & 3396247933 \\
\hline 2015 & 313446000 & 10061375860 & 125484 & 850054 & 2856234330 \\
\hline 2016 & 192178000 & 14069780252 & 144484 & 1093159 & 2076559972 \\
\hline 2017 & 207220000 & 15777466100 & 193447 & 914962 & 1787126321 \\
\hline
\end{tabular}

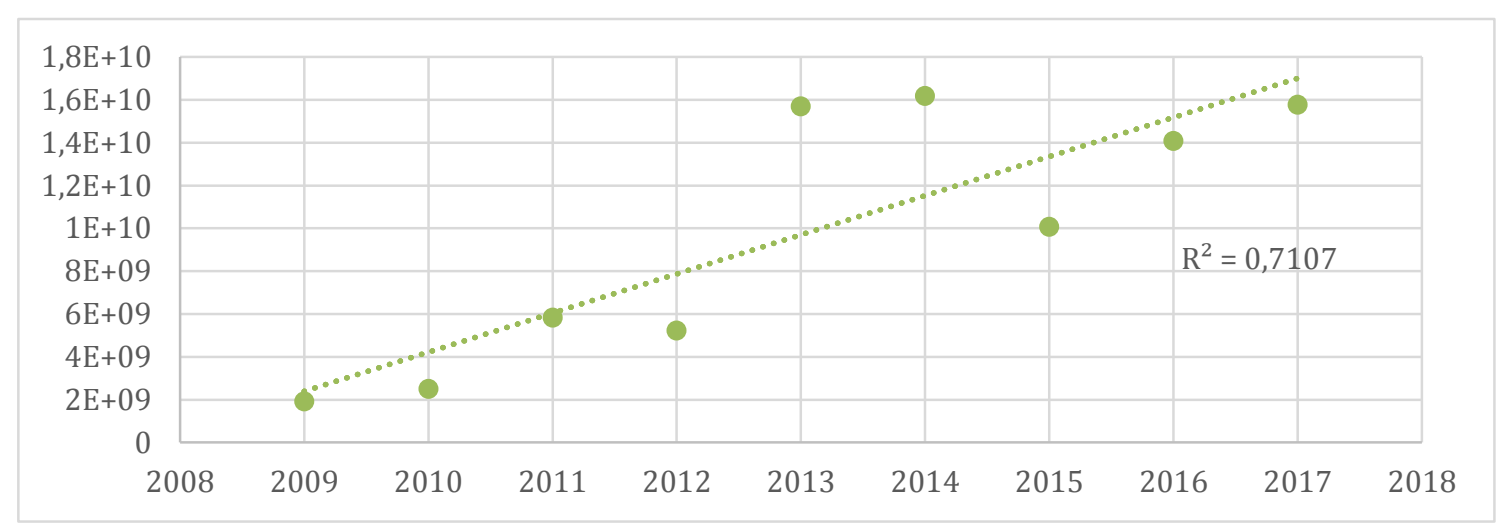

Figure 3. The graphic showed the amount of inflow of FDI in billion dollar for high-technology sector in Kazakhstan from 2009-2017 years (source: Committee of Statistics of the Ministry of National Economy of the Republic of Kazakhstan calculated by the author)

This Figure 3 provides information regarding government spending on R\&D investments from 2009-2017. Based on this figure, it is seen that a positive value of the correlation coefficient is displayed.

Table 4. The result of the correlation of coefficiency of the factors of the high-technology sector in Kazakhstan (source: Ministry of National Economy of the Republic of Kazakhstan Statistics committee, Knoema Enterprise Data Solutions, The World Bank calculated by the author)

\begin{tabular}{|l|c|c|c|c|c|}
\hline \multicolumn{1}{|c|}{ Indicators } & $\begin{array}{c}\text { Government } \\
\text { spending on } \\
\text { R\&D }\end{array}$ & $\begin{array}{c}\text { The inflow of FDI } \\
\text { for the high tech } \\
\text { sector }\end{array}$ & $\begin{array}{c}\text { Government } \\
\text { investment }\end{array}$ & $\begin{array}{c}\text { Private } \\
\text { Enterprise } \\
\text { Costs }\end{array}$ & $\begin{array}{c}\text { High-tech } \\
\text { export }\end{array}$ \\
\hline Government spending on R\&D & 1,00 & & & & \\
\hline The inflow of FDI for the high tech sector & 0,20 & 1,00 & & & \\
\hline Government investment & 0,13 & 0,11 & 1,00 & & \\
\hline Private Enterprise Costs & 0,15 & 0,53 & $-0,49$ & 1,00 & \\
\hline High-tech export & 0,86 & 0,15 & 0,42 & 0,08 & 1,00 \\
\hline
\end{tabular}

This Table 4 shows the results of the relationship between the High-tech sector output value and the input value as Government spending on R\&D, The inflow of FDI for the high tech sector, Government investment, Private Enterprise Costs. In the result, the data indicated to present a high relationship between the High-tech export and Government spending on R\&D indicators, another ratio of indicators showed a weak dependent relationship between High-tech export and Government investment. The remaining values such as The inflow of FDI for the high tech sector and Private Enterprise Costs are closer to 0.2, which indicates a very weak connection between the values. To proceed to the calculation of regression analysis, the factors that represent a strong relationship such as High-tech Export and Government spending on R\&D were selected from the result of the correlation coefficient. 
The results obtained from the correlation analysis allowed us to find out the level of interdependence of the selected factors. Based on the results, elements such as High-tech export and Government spending on R\&D were used to further research them. Table 5 were illustrated to us the application of regression analysis how significant they are.

Table 5. The obtained result from regression analysis

\begin{tabular}{|l|c|}
\hline $\begin{array}{c}\text { Regression } \\
\text { statistics }\end{array}$ & \\
\hline Multiple R & 0,86 \\
\hline R-squared & 0,74 \\
\hline $\begin{array}{l}\text { Normalized } \\
\text { R-squared }\end{array}$ & 0,71 \\
\hline $\begin{array}{l}\text { Standard } \\
\text { error }\end{array}$ & 358251270,1 \\
\hline Observations & 9 \\
\hline
\end{tabular}

\begin{tabular}{|l|c|c|c|c|c|}
\hline $\begin{array}{c}\text { Analysis of } \\
\text { variance }\end{array}$ & $d f$ & $S S$ & $M S$ & $F$ & Significance $F$ \\
\hline Regression & 1 & 2613901182705550000 & 2613901182705550000 & 20,36637 & 0,002755 \\
\hline The Balance & 7 & 898407807814693000 & 128343972544956000 & & \\
\hline Total & 8 & 3512308990520240000 & & & \\
\hline
\end{tabular}

\begin{tabular}{|l|c|c|c|c|c|c|c|c|}
\hline \multicolumn{1}{|c|}{ Indicators } & Coefficients & $\begin{array}{c}\text { Standard } \\
\text { error }\end{array}$ & t-statistic & P-value & $\begin{array}{c}\text { Lower } \\
95 \%\end{array}$ & $\begin{array}{c}\text { Top } \\
95 \%\end{array}$ & $\begin{array}{c}\text { Lower } \\
95 \%\end{array}$ & $\begin{array}{c}\text { Top } \\
95 \%\end{array}$ \\
\hline $\begin{array}{l}\text { High-tech } \\
\text { export }\end{array}$ & 431304765,3 & 499395183,4 & 0,9 & 0,4 & $-749577196,5$ & 1612186727 & $-749577196,5$ & 1612186727 \\
\hline $\begin{array}{l}\text { Government } \\
\text { spending on } \\
\text { R\&D }\end{array}$ & 7,51 & 1,66 & 4,5 & 0,0 & 3,6 & 11,45 & 3,58 & 11,45 \\
\hline
\end{tabular}

In this study, were presented the results of a regression analysis where, "Multiple R" is the correlation coefficient that is 0.86 , "R-square" is the determination coefficient is 0.74 (Kurzaeva, 2015) mentioned that If the $R$-square <0.6, it is assumed that the accuracy of the approximation is insufficient and the model requires improvement "Coefficient: High tech export" - a free member of the regression equation 431304765,3; "Government spending on R\&D" - coefficient of regression -7.51. There are also values of the Fisher F-criterion 20.36637”, which are necessary to assess the significance of the correlation coefficient, parameters of the regression equation and the entire equation.

Based on the data from the table, we constructed the equation of regression: $y x=431304765.3+7.51 x$. The coefficient of regression of Government spending on $R \& D=7.51$, it is mean that if the investment of $R \& D$ increase,so the indicator of High-tech export in Kazakhstan will also increase.

Also, the correlation coefficient is $r=0.86$, it is greater than the value of the correlation modulus of 0.85 , therefore, the relationship between the studied characteristics in this aggregate is quite close. The coefficient of determination $\mathrm{r}^{2}=0.74$ shows that $74 \%$ of the variation of the productive feature (export of high-tech products) is caused by the action of the factor's feature (investment costs for R\&D).

In the table of critical points of the Fisher-Snedecor distribution, we founded the critical value of the F-criterion at a significance level of 0.05 and the number of free degrees $\kappa_{1}=\mathrm{m}-1=2-1=1$ where $\mathrm{m}$ is the number of factors and $\mathrm{k}_{2}=\mathrm{n}-\mathrm{m}=9-2=7$, where the $\mathrm{n}$ is a sample size, is 5.59. Since the calculated value of the criterion is more than the tabular one $(F=20.36637>5.59)$, the regression equation is considered significant.

\section{Conclusions}

This assignment has explained the central importance of different barriers related to the high-technology sector in the context of internationalization. Also proved that the process of internationalization was strongly interdependent with the high-tech sector. By the way, there are many countries considered the internationalization process more profitable especially for high-tech subjects. It is analyzed that some authors divided the main barriers into two groups such as internal and external, also examining other materials we found some additional barriers like bribery, bureaucracy, high cost of internationalization which were described. The main feature is that barriers can associated with the development of countries. 
Additionally, some authors highlighted the most common issues which have an attitude to management, marketing fields. At the end of this task, it was analysed the problems and elements which influence the hightechnology sector in Kazakhstan. Analyzing the scientific studies we took suitable problems which experienced the government and companies.

In this investigation, the aim was to took an appropriate method such as regression and correlation analysis to calculate the factors and to identify a significant factor and determine how significant they are. In the survey were taken factors that impacted to the development of high- tech sector, like Government spending on R\&D, The inflow of FDI for the high tech sector, Government investment, Private Enterprise Cost, the Export of high-tech goods. From the result of the investigation of the practical part let us conclude that only two elements out four, such as Government spending on R\&D and the Government investment showed a positive position for high-technology sector more precisely for exports of high-tech products. Other values like The inflow of FDI for the high tech sector and Private Enterprise Costs illustrated the worst connection, their values were closer to 0.2.

The regression analyses indicated the significance of these components when the correlation showed their dependence.

When carrying out the calculation using regression analysis, the values of Government spending on R\&D and High-tech export were used, while other factors represented weak indicators of dependence.

During the study, the data of the High tech export and Government spending on R\&D indices were studied from 2009-2017. It is considered necessary to assess the significance of the correlation coefficient and regression parameters such as Multiple $\mathrm{R}$ is the correlation coefficient, R-square is the determination coefficient, Coefficient: "High tech export" - a free member of the regression equation and "Government spending on R\&D"and the Fisher value. Subsequently, these indicators satisfy the positive signs of growth in the high-tech sector of Kazakhstan. Besides, they fully justified their importance both for the growth of the high-technology sector and for participation in the internationalization process.

Past scientific researches make it clear that in most cases, knowledge in the high-tech sector is developed only by studying its barriers, development prospects, creating models and development programs. However, in this paper, we study the factors affecting the development of the high-tech industry in Kazakhstan. In the study of these factors, we observed that only one factor (Government R\&D expenditures) was of great importance for the growth of the high-tech industry in Kazakhstan. Therefore, we are considering the idea to attract additional data such as (import of high-tech products, international organization loans) to get the full result for our next study.

From our point of view, the acquired values in this investigation are a recommendation for the subjects of the high-tech sector like the state, domestic enterprises, foreign companies. In other words, for the state, the acquired result will allow us to assess the current state of the high-tech industry. The government and enterprises should activate their mechanisms to involve and motivate opportunities for innovation. Everyone knows how the modern high-tech market works, the availability of capital will be an obvious condition for their occurrence. For example, The creating and investing in a venture fund will allow the government to step up small businesses and secure financing for hightech industry projects. The government should accelerate attractive conditions for attracting more FDI and develop the interest of domestic companies in investing in the high-tech sector.

Limitation. The primary limitation of these results was the absence of data for imported high-tech products. We believe, it was happened due to the limited data on the official statistical resources of Kazakhstan, likewise international statistical resources in general. We expected to use these data but as a result of difficulties with limited access, the result of the study was not complete. Consequently, it is necessary to take into account that the obtained positive result suffers from the influence of limiting factors like inflow of FDI, Government spendings, Private Sector Expenditures affecting the development of the high-tech sector.If additional information were available, this would contribute to the achievement of additional results. Our study examined the effectiveness of the influence of certain factors on the development of the high-tech industry in Kazakhstan. However, these results in the future could be used to analyze factors and barriers affecting the development of the high-tech sector in developing countries.

Main value of this study was showed that scientific articles of the high-tech sector of Kazakhstan experienced barriers, innovative development programs, main development priorities, new innovative development models in total. We considered it also necessary to study the presence of key factors such as inflow of FDI, Government spendings, Private Sector Expenditures that affect the growth of the high-tech sector in Kazakhstan. Likewise, to consider their levels of value using data from the period 2009-2017.

\section{References}

Aldrich, J. (2005). Fisher and regression. Statistical Science, 20(4), 401-417. https://doi.org/10.1214/088342305000000331 Aslanbek, A. (2014). The future of Kazakhstan in hi-tech style (pp. 1-4). Kazakhstan, Almaty. http://www.nauka.kz/page.php?page_id=932\&lang=1\&article_id=5857

Brezink, C. (2014). Technology transfer and business innovation (pp. 1-41). Vienna, Austria. https://www.interregcentral.eu/content.node/1-technology-final.pdf

Chelm, T., Sholc, N., \& Oshakbaiev, R. (2017). Transformation of the economy of Kazakhstan. Astana, Kazakhstan. 212 p. 
Daszkiewicz, N. (2019). The internationalization of high-tech firms, patterns, innovation and research and development (pp. 1-30). Cambridge Scholars Publishing.

Dnishev, F., Alzhanova, F., \& Korgaspekov, D. (2016). Formation of the new policy of innovative development of Kazakhstan in the context of current innovation models. 6(S5), 49-60. www.econjournals.com

Dukenbayev, Y. (n.d.). Technology transfer in Kazakhstan problems, prospect and possibilities for foreign companies. http://webcache.googleusercontent.com/search?q=cache:zKI7c8yfoyQJ:www.aspa.or.kr/files/webzinevol.9_050824/05 0824_ASPA\%2520paper13_eg.htm\&hl=ru\&gl=lt\&strip=1\&vwsrc=0

Gingrich, P. (2004). Association between variables. In Introductory statistics for the social sciences (Chapter 11, pp. 794-835). Department of Sociology and Social Studies University of Regina CL217.

Iljin, V. (2013). Correlation analysis quantitative variables in medical-biological researches. Scientific Centre of Family Health and Human Reproduction Problems SB RAMS, 4(92), 125-130. Irkutsk, Russia.

Khachaturov, A., \& Belkovskiy, A. (2007). Management in Russia and abroad (pp. 1-4). Moscow, Russia.

Kos-Łabędowicz, J. (2013). Influence of modern technologies on internationalization of small and medium enterprises. Information Systems in Management, 2(1), 12-22.

Krikštulytė, R., \& Korsakienè, R. (2016). The barriers and motives of SMEs internationalization: The insights into the theory development. In $9^{\text {th }}$ International Scientific Conference "Business and Management 2016" (pp. 1-9). https://doi.org/10.3846/bm.2016.67

Kurzaeva, L. (2015). Regression analysis in spreadsheets. International Journal of Applied and Fundamental Research, 12. NosovMagnitogorsk State Technical University, Magnitogorsk, Russia.

Melnikas, B. (2014). High technologies sector under the conditions of the European integration: Innovative development. Procedia - Social and Behavioral Sciences, 110, 28-39. https://doi.org/10.1016/j.sbspro.2013.12.845

Ramcharan, R. (2006). Regressions: Why are economists obessessed with them? International Monetary Fund, 43(1). https://www.imf.org/external/pubs/ft/fandd/2006/03/basics.htm

Sekliuckiene, J., \& Maciulskaite, S. (2013). Internationalization decision of a born global: The case of information technology companies. Social Sciences, 80(2), 17-26. https://doi.org/10.5755/j01.ss.80.2.4644

Shalabh, S. (n.d.). Simple linear regression analysis (pp. 1-42). Indian Institute of Technology, Kanpur, India.

Singh, G., Pathak, R. D., \& Naz, R. (2010). Issues faced by SMEs in the internationalization process: results from Fiji and Samoa. International Journal of Emerging Markets, 5(2), 153-182. https://doi.org/10.1108/17468801011031801

Taylor, R. (1990). Interpretation of the correlation coefficient: A basic review. Journal of Diagnostic Medical Sonography, 6(1), 35-39. https://doi.org/10.1177/875647939000600106

Vasilyev, A. (2012). Review of innovative development of Kazakhstan. European Economic Commission United Nations, 1 206. New York and Geneva.

Žemaitis, E., Vilys, M., \& Jakubavičius, A. (2016). High technology sector internationalisation: open innovation perspective. Journal of System and Management Sciences, 6(2), 33-51. 